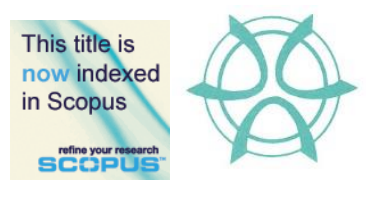

PLANNING MALAYSIA:

Journal of the Malaysian Institute of Planners

VOLUME 16 ISSUE 3 (2018) Page 83 - 96

\title{
EVALUATION OF INFILL BUILDING BLOCK IN HERITAGE SCHOOLS IN KUALA LUMPUR
}

\author{
Mohd Amirul Hakim Zamri' ${ }^{1}$ \& Jamalunlaili Abdullah ${ }^{2}$ \\ ${ }^{1,2}$ Faculty of Architecture, Planning and Surveying \\ UNIVERSITI TEKNOLOGI MARA, MALAYSIA
}

\begin{abstract}
In Kuala Lumpur, there are a few heritage schools that are more than 100 years old which have experienced significant infill developments since colonial era. This study evaluates the infill building structures and proposes a suitable design approach of infill development in heritage school. It focuses on the infill development theory, reviews on the physical aspect of heritage school buildings as well as related local policies and guidelines. In order to achieve the research purpose and objectives, the study uses the qualitative methodology. The study found that there are 2 infill design approaches, which is the complementary design approach and contrast design approach and both can be used as long as compatible and in harmony with the existing heritage building and site. Through site observation survey, it was found that although infill development at St John's Institutions and Maxwell Secondary Schools adopted the contrast approach, the outcome were different. Infill development at St John's Institutions was compatible and in harmony, while at Maxwell Secondary School was the opposite. Therefore, this study suggests improvement on the existing infill structures in the heritage school, either through image restoration or transfer of facilities to future development. Other recommendation include the government providing infill development guidelines for heritage site, encouraging private sector to participate in heritage school conservation and development, and controlling the height of new development within 100 meter radius from heritage buildings.
\end{abstract}

Keywords: heritage school, urban infill, Maxwell School, St John Institution 
Mohd Amirul Hakim Zamri \& Jamalunlaili Abdullah

Evaluation of Infill Building Block in Heritage Schools in Kuala Lumpur

\section{INTRODUCTION}

Malaysia has diverse heritage buildings that demonstrate the features and characteristics of local and international architecture, as well as outstanding craftsmanship. Some are located in Kuala Lumpur, the capital and largest city in the country. It has been estimated that the number of historical heritage buildings in Kuala Lumpur is $8.4 \%$ of the country's total which equals to 1,763 unit number of buildings (Kamarul, 2008 cited by Alauddin, Ishakt, Mohd Isa, \& Mohamad Sohod, 2016). There are many colonial heritage buildings with western architecture styles such as Moghul style for institutional buildings and Art deco style for shophouses.

Along with other colonial buildings, heritage schools have long been known for their unique architectural characteristics and contribution to local historical development. They include Victoria's Institution (established in1893), St John's Institution (1904), Maxwell Secondary School (1924), SMK Convent Bukit Nanas (1899), Batu Road Prime School (1930), Methodist Girl's School Brickfield (1896), SMK Confucian Kuala Lumpur (1906) and Methodist Girl's School Kuala Lumpur (1916). These schools are considered some of the finest examples of historical heritage buildings and sites. Thus, they should be studied and preserved as education heritage of Malaysia.

The rapid growth of Kuala Lumpur's population increases the demand for new space for education facilities. Parents have always wanted to send their children to schools with excellent academic reputations. Most of the heritage schools in city centre such as St John's Institution, Maxwell Secondary School and Convent School Bukit Nanas are categorised as cluster schools by the Malaysian Ministry of Education, which have excellent record of educational achievements. This increased demand from parents to enrol their children into the schools has forced the addition of learning spaces and facilities, which were built through infill development within the compound of the existing heritage schools.

According to Center for Urban Policy Research (2006), infill development is a key component of smart growth which usually occurs in central cities and inner suburbs on scattered sites where there is a vacant pocket that can be developed. However, infill development may create conflict between the new and the old buildings or site setting where the new building's scale, details, structure and function are alien to the old's. The heritage schools' infill structures and building blocks seem to have several distinctive architecture approaches and styles or school of thought. The new extension structure or new adjacent building block which is connected to the existing heritage buildings seem insensitive or not respecting the existing heritage building block (Abdullah, Ahmad Zaki, \& Syed Subli, n.d). The question is, what are the considerations or variables that are taken into account in designing new infill building blocks of heritage schools?

Moreover, the placement of lateral extension or new infill building block in the school physical planning development also has given significant impact to 
PLANNING MALAYSIA

Journal of the Malaysia Institute of Planners (2018)

the overall heritage school image. The structural massing of infill building blocks also plays a significant role in affecting the whole scenery of heritage school image in which they look bigger, bolder and more prominent compared to the heritage building block. Thus, what are the factors and forces that influenced the heritage school physical planning over the years regarding the building placement and the structural massing? It seems like the development of infill building structure of heritage school does not fit the objective of heritage building conservation set by the government.

\section{Urban Infill Development in Historical Site Setting}

According to Rotondo, Selicato, Marin and Galdeano (2018), the word 'heritage' was derived from Latin patri-monium, which means 'things belonging to his father'. It can be defined as a set of goods that have been inherited from our fathers or previous generations, and that can be passed on to future generations. The 19th General Assembly of the International Council on Monuments and Sites (ICOMOS) 2017 in Delhi defined heritage as the declaration of human movement and methods for living all through history passed on from generation to generation. In addition, the 11th ICOMOS stated that the heritage or cultural heritage refers to the monuments, groups of buildings and sites of heritage value, constituting the historical built environment.

Schultz and Kasen (1991) define infill as a residential or non-residential development that occurs on vacant land that are scattered among developed areas of municipalities. Meanwhile, Davis (2004) defines that infill is development on empty land in urbanized regions and redevelopment of areas that are adjacent to urban development where all services and facilities are anticipated to have the capacity to accommodate additional demand. Thus, urban infill can be defined as a new development in an empty parcel or a vacant lot within the developed area, which can be a new development, redevelopment or restoration works.

There are two approaches of infill architectural design, which are complementary and contrast approaches. The complementary approach is the architectural approach based on the architectural visual style theory that follow the character of neighbouring buildings. Contrast approach is the architectural approach based on the rationalist or systematic architectural theory which develop the design based on the calculations, functions, moralities and the issues of the present (Alfirevic \& Somonovic-Alfirevic, 2015).

\section{RESEARCH METHODOLOGY}

This research on infill development was conducted at two heritage schools in Kuala Lumpu, which were St John's Institution (SJI) at Jalan Bukit Nanas and Maxwell School (MXS) at Jalan Tun Ismail. The two schools were selected from nine heritage schools in Kuala Lumpur using Pairwise Comparison analysis technique based on the criteria of 'the most significant infill development' in 
Mohd Amirul Hakim Zamri \& Jamalunlaili Abdullah

Evaluation of Infill Building Block in Heritage Schools in Kuala Lumpur

heritage school sites. The criteria include percentage of infill building block within the school compound, the impact of architectural design and the block massing comparison between the heritage and infill block.

This study adopted a qualitative research approach. Literature review includes historical and background analysis of heritage colonial schools in Kuala Lumpur, architectural design philosophy associated with the infill design in historical site setting as well as local policies and guidelines on works related to heritage site setting. Data were gathered through observation surveys on the two selected heritage schools in Kuala Lumpur and expert interviews. The observation survey data were photographed and analysed using descriptive and comparative techniques on five criteria which were heritage school external planning context, internal planning arrangement, architectural design approach, construction method and block massing.

Meanwhile, interview sessions were conducted with practitioners and experts in the field of architecture and heritage, which include architects, heritage conservators and the local authority. The interviews were based on semi structured questions related to the respondents' field of expertise.

\section{FINDINGS AND DISCUSSION}

\section{Site Observation Survey}

This section presents the analysis and findings from site observation survey. This section also includes a short discussion regarding the infill development inside and outside of heritage schools compound. The observation survey evaluated five criteria which are listed in Table 1. The table also summarizes the findings of the survey.

Table 1: Findings from observation survey

\begin{tabular}{|c|c|c|c|}
\hline $\begin{array}{l}\text { The } \\
\text { criteria }\end{array}$ & SJI & MXS & Analysis / comment \\
\hline 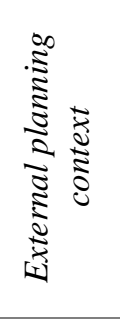 & $\begin{array}{l}\text { Is not affected by } \\
\text { surrounding urban } \\
\text { development because } \\
\text { it is located near forest } \\
\text { reserve area and } \\
\text { within heritage } \\
\text { building zone in the } \\
\text { city }\end{array}$ & $\begin{array}{l}\text { The heritage school is } \\
\text { surrounded by rapid } \\
\text { urban development } \\
\text { that gives an adverse } \\
\text { impact to the overall } \\
\text { school development }\end{array}$ & $\begin{array}{l}\text { The location in an } \\
\text { urban area is the main } \\
\text { factor that influences } \\
\text { the heritage schools } \\
\text { development }\end{array}$ \\
\hline
\end{tabular}


PLANNING MALAYSIA

Journal of the Malaysia Institute of Planners (2018)

\begin{tabular}{|c|c|c|c|}
\hline 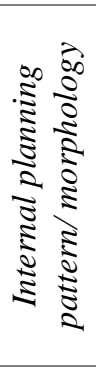 & $\begin{array}{l}\text { The overall school } \\
\text { layout planning is } \\
\text { consistently developed } \\
\text { and projected toward } \\
\text { the rear side of the } \\
\text { school and erected } \\
\text { once per every } 16 \\
\text { years on average }\end{array}$ & $\begin{array}{l}\text { The overall school } \\
\text { layout planning is } \\
\text { developed scattered } \\
\text { within school area } \\
\text { because of limitation } \\
\text { of school space, } \\
\text { development cost and } \\
\text { external urban } \\
\text { development }\end{array}$ & $\begin{array}{l}\text { SJI development } \\
\text { planning is more } \\
\text { organised compared to } \\
\text { MXS because of } \\
\text { different external } \\
\text { urban force }\end{array}$ \\
\hline 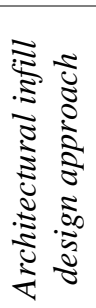 & $\begin{array}{l}\text { Generally, used } \\
\text { contrast technique } \\
\text { with certain } \\
\text { development theme } \\
\text { that follows the trend } \\
\text { of architecture style at } \\
\text { the time it was built }\end{array}$ & $\begin{array}{l}\text { Generally, used } \\
\text { contrast technique but } \\
\text { somehow does not } \\
\text { have major theme for } \\
\text { overall development } \\
\text { design scheme }\end{array}$ & $\begin{array}{l}\text { Infill development of } \\
\text { both schools used } \\
\text { contrast approach, but } \\
\text { the theme of } \\
\text { development creates } \\
\text { different results }\end{array}$ \\
\hline 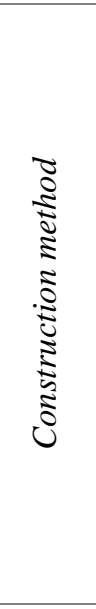 & $\begin{array}{l}\text { Construction method } \\
\text { follows common } \\
\text { construction } \\
\text { technology of the } \\
\text { time. It is due to the } \\
\text { school development } \\
\text { was not affected by } \\
\text { limited time \& cost } \\
\text { constraint at the time it } \\
\text { was built because the } \\
\text { infill developments } \\
\text { were erected mostly in } \\
\text { the colonial era and } \\
\text { fully funded by the } \\
\text { private sector }\end{array}$ & $\begin{array}{l}\text { Overall development } \\
\text { pattern shows that the } \\
\text { school emphasised on } \\
\text { prevailing technology } \\
\text { that can save time and } \\
\text { cost of infill project. } \\
\text { Infill developments } \\
\text { were constructed after } \\
\text { Independence, } \\
\text { supported by limited } \\
\text { government budget } \\
\text { within limited time } \\
\text { frame }\end{array}$ & $\begin{array}{l}\text { The time period and } \\
\text { funding availability } \\
\text { affect the construction } \\
\text { technology used in } \\
\text { infill development }\end{array}$ \\
\hline 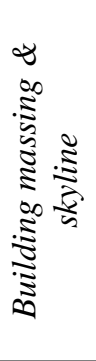 & $\begin{array}{l}\text { Scales \& heights of } \\
\text { building blocks are } \\
\text { similar. The } \\
\text { development skyline } \\
\text { looks harmonious and } \\
\text { compatible with each } \\
\text { other }\end{array}$ & $\begin{array}{l}\text { Building massing } \\
\text { scales and heights are } \\
\text { inconsistent resulting } \\
\text { in the infill buildings } \\
\text { overshadowing the } \\
\text { heritage building. It } \\
\text { resulted in } \\
\text { incompatible building } \\
\text { skyline }\end{array}$ & $\begin{array}{l}\text { The development } \\
\text { skyline result from the } \\
\text { forces of surrounding } \\
\text { development, the } \\
\text { development timeline } \\
\text { and construction } \\
\text { technology used }\end{array}$ \\
\hline
\end{tabular}


Mohd Amirul Hakim Zamri \& Jamalunlaili Abdullah

Evaluation of Infill Building Block in Heritage Schools in Kuala Lumpur

\begin{tabular}{|c|c|c|c|}
\hline 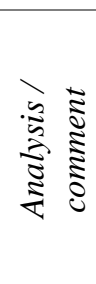 & $\begin{array}{l}\text { The development } \\
\text { design of SJI infill } \\
\text { building looks well } \\
\text { organised \& does not } \\
\text { adversely affect the } \\
\text { appearance of the } \\
\text { heritage building }\end{array}$ & $\begin{array}{l}\text { The development } \\
\text { design of MXS infill } \\
\text { building looks } \\
\text { disorganised and } \\
\text { affected the } \\
\text { appearance of the } \\
\text { heritage building }\end{array}$ & $\begin{array}{l}\text { The outcome of the } \\
\text { infill development is } \\
\text { influenced by urban } \\
\text { development pressure, } \\
\text { site location, } \\
\text { development cost and } \\
\text { architectural style }\end{array}$ \\
\hline
\end{tabular}

\section{Heritage School External Planning Context}

$\mathrm{SJI}$ is located in an area surrounded by other colonial heritage buildings and forest reserve, which discourage new development in the area. Thus, the internal planning of this heritage school have been developed in a well-organised manner because it has choice and space to arrange the infill building blocks from time to time. MXS, on the other hand, is located in the middle of a rapidly developing area of Kuala Lumpur. Thus MXS received a great urban development pressure compared to SJI resulting with the former losing some land to other urban development. Thus, it affected the MXS lateral planning arrangement due the compactness of school site. Thus, the study found that external development force could give significant influence to the internal development of heritage school (Figure 1).
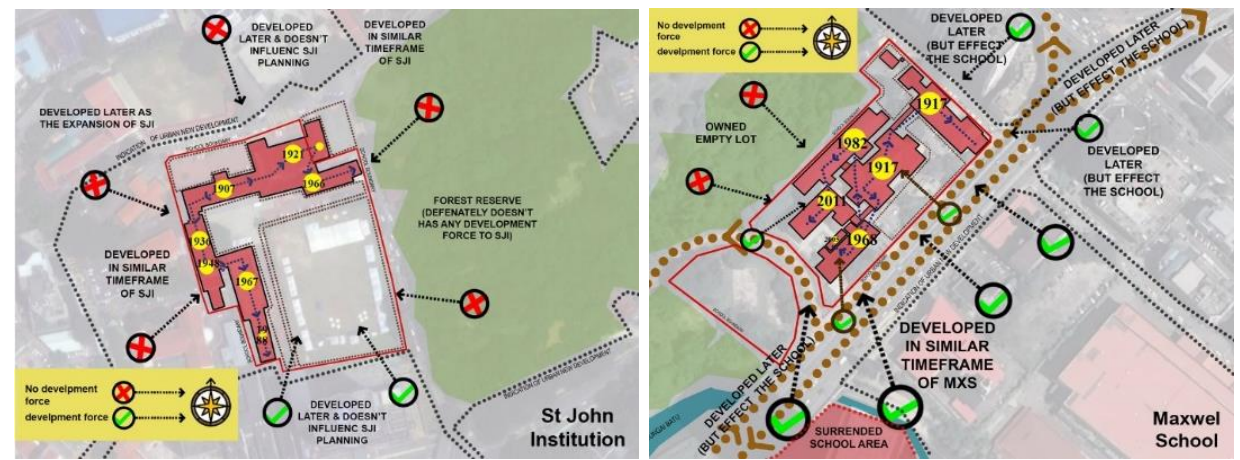

Figure 1: Comparison of the external development force toward heritage school

\section{Internal Planning Arrangement of Heritage School}

Generally, both heritage schools development pattern is directed toward the rear side of the school. However, SJI's infill development was more organised and concentrated compared to MXS's whose block placements are scattered. SJI infill development took place once every 16 years, on average. SJI did not receive external urban development pressure from surrounding area, which allowed it to expand the facilities in organised manner. MXS is the opposite; its infill development was not well organised and followed inconsistent timeline. It is due 
PLANNING MALAYSIA

Journal of the Malaysia Institute of Planners (2018)

to the adverse impacts of surrounding development and the limitation of space within the school compound due to its land being taken away by other urban uses.

\section{The Architectural Design Approach of Infill Block}

The study found that both heritage schools deployed architectural contrast design approach in which they did not follow their original school block design. However, their development strategy was different to one another, leading to different end results. SJI infill development was developed with a theme whereby every infill bloc was developed by following the periodic architectural style at the time it was erected. On the other hand, MXS development strategy did not have a proper architectural design timeframe. The infill developments in MXS were developed with limited cost, time and space.

Most of SJI infill blocks were erected before the independence of Malaya, and was financially well supported by the colonial government and the church. In contrast, MXS's infill blocks were developed after the independence of Malaya with limited budget. Consequently, it had to follow standard Public Works design which was insensitive towards existing heritage building.

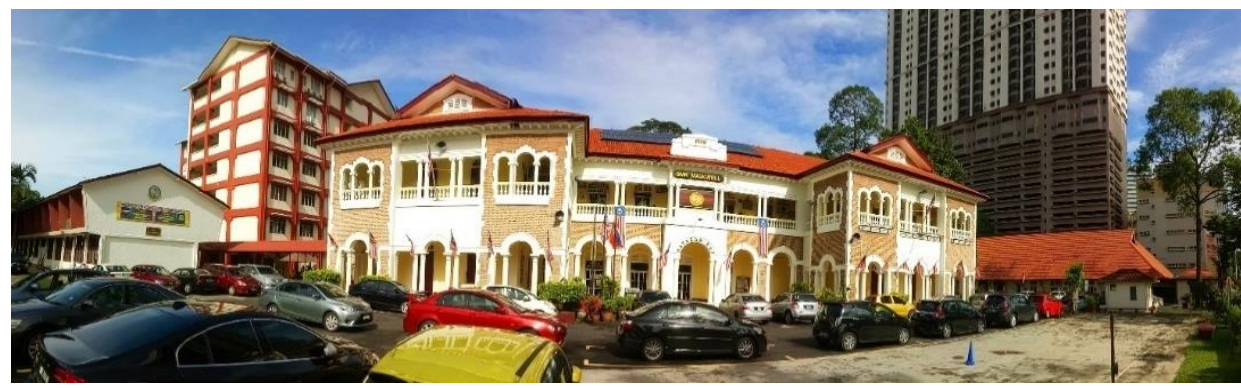

Figure 2: Panoramic view toward Maxwell school

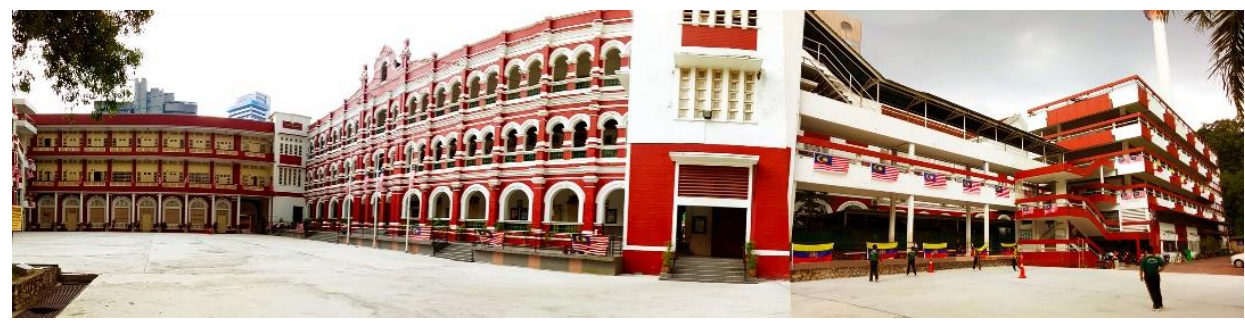

Figure 3: Panoramic view toward the rear of St John's Institution

\section{Construction Method}

The study found that the construction of both heritage schools followed the construction technology at the time they were developed. SJI construction method evolved from the load bearing method to the post and beam construction method. Meanwhile, MXS construction method evolved from the load bearing 
Mohd Amirul Hakim Zamri \& Jamalunlaili Abdullah

Evaluation of Infill Building Block in Heritage Schools in Kuala Lumpur

method to IBS construction method. The construction methods chosen were influenced by the time efficiency of development, the cost of construction and the external urban development pressure. MXS used the IBS method to meet the time and cost efficiency of recent development, but SJI infill development followed mainstream approach of construction method of the time.

\section{Building Block Massing}

SJI building massing size is consistent and developed in a similar range of height among the building blocks. However, MXS building massing design is inconsistent where the much taller infill building overwhelmed the heritage blocks (Figure 4). It is due to the difference in space provision within the school compounds at the time they were developed.

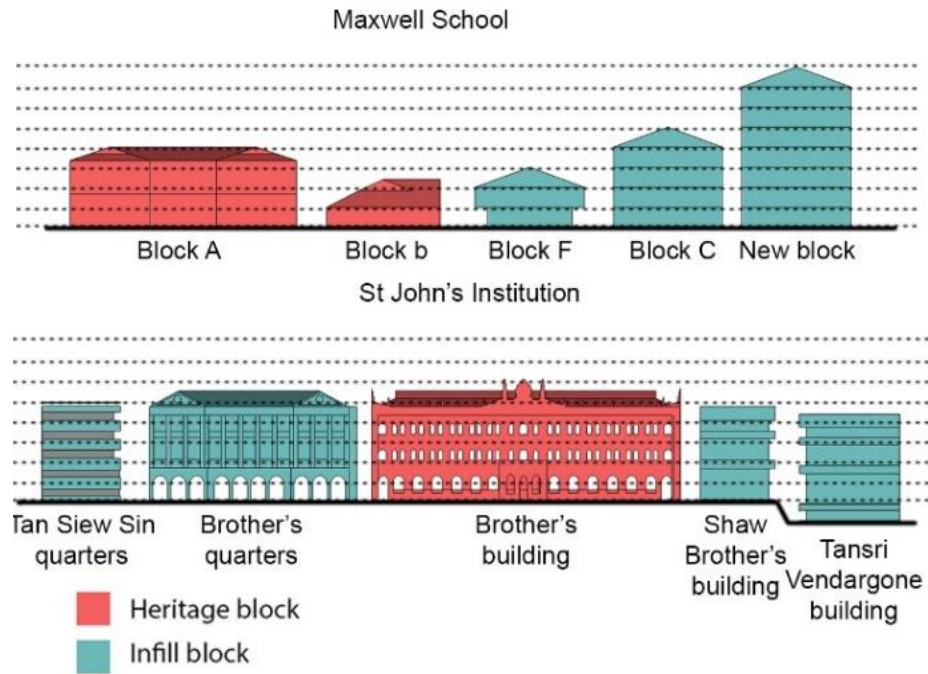

Figure 4: Block massing comparison of SJI and MXS

In summary, heritage building conservation development especially heritage schools faced a multitude of challenges to maintain their heritage significance. There are various factors to be considered which affected the outcomes. These include location of the site, limitation of space, the period of development, the context characters, the technologies of construction and the cost considerations.

\section{Expert Interviews}

In the expert interview, two themes of questions were to be answered by the experts. The first theme was about their understanding of architectural design compatibility to the surrounding area and the best infill development approach to 
PLANNING MALAYSIA

Journal of the Malaysia Institute of Planners (2018)

historical site setting. The second theme covered existing policies and guidelines of infill development related to heritage school development in Kuala Lumpur.

The interview results indicate that the architectural design is compatible and in harmony with the site context when the design has a value of 'contextualism' and 'sympathetic' to the site. Both infill design approaches, complementary and contrast approaches, are relevant to be applied in the heritage site setting as long as they respond to the site context, contribute a good impact to the heritage site and fulfil the current needs. In addition, for the infill development that uses the contrast approach, there are four criteria that the development must follow which are: the structure of infill building should be designed in the passive mode, low profile, complementing and do not overshadow the main heritage building. It is to respect the existing historical heritage building, which contributed to the society for so long. Infill block also must not block the majestic view toward the heritage building and does not disrupt the harmony of the site.

Even though the infill is in the passive mode, infill block must have a significant design concept so that it can help enhance the value of heritage site. However, to achieve the value of compatibility to the site context, it does not mean the design of infill block need to replicates or mimics the existing building's. Moreover, every infill development in heritage site must follow the Garis Panduan Pemuliharaan Bangunan Warisan (Heritage Building Conservation Guidelines) by the National Heritage Department (JWN) and guidelines of building retention within Kuala Lumpur City Centre by Kuala Lumpur City Hall (DBKL). However, there is no specific guideline for architectural style and feature of a public school. There is only a guideline of spatial programme standard sizes in Garis Panduan dan Peraturan Bagi Perancangan Bangunan (EPU) 2015. The policies and guidelines for infill development that involve heritage conservation in Kuala Lumpur generally are well developed and organised but they need to be improved and detailed out on the architectural design criteria for infill development in heritage site.

In terms of the two case studies, the experts were of the opinion that the infill at SJI was better and more sympathetic to the original heritage building compared to that of MXS. While infill in both case studies adopted the contrast approach, the result at SJS has a better contextualism component of development.

\section{CONCLUSION AND RECOMMENDATIONS}

There are few conclusion of findings of this study. It found that the external factors do play a role in influencing the heritage school development. Due to this external force of development in surrounding areas the SJI development is more organised compared to MXS. The internal force that influences the infill development are funding availability, construction technology and the time period of infill development. Thus the outcome of the infill development is 
Mohd Amirul Hakim Zamri \& Jamalunlaili Abdullah

Evaluation of Infill Building Block in Heritage Schools in Kuala Lumpur

influenced by the urban development pressure, site location, development cost and architectural style.

Based on the findings of this research, several recommendations were formulated. These recommendations may also apply to areas with similar characteristics and problems. The recommendation is divided into two sections, which are the recommendation on the internal planning of heritage school and the recommendation on the development adjacent to the heritage school.

\section{Recommendation on the Internal Planning of Heritage School}

\section{Ideal Approach to Architectural Infill Design}

This study recommends using the contrast approach in heritage school infill development. This is to differentiate the old historical buildings with the new infill buildings, to highlight the heritage building and as a compliment or backdrop for the historical heritage building. The building features of infill building design have to be sensitive to the character of existing heritage buildings. The infill building height must be within the range of existing heritage building height, and the building façade colour have to be lighter and 'fade' than the heritage building.

\section{Adjustment to Existing Infill Buildings of Heritage Schools and Future Planning}

For the built infill buildings in SJI and MXS, some minor adjustments on the buildings need to be carried out. These are to make the infill building façade look more related to the heritage building. Considering practicality, school operation and the cost of development, the approach proposed is complementary approach, in which the large building block or structure that are still in use will not be demolished. The adjustment works can be made either through building façade design features, or the changes in linkage design or roofing design, and building colour.

It is also recommended that future extension or infill development of heritage school can only be developed toward the rear of the school area. No new structure or building blocks should be developed at the front area of the school which will block the view toward the heritage building block. The government should assist the heritage school to acquire the adjacent land to develop new facilities if the space within school compound was limited. Figure 5 shows the recommendation for SJI and MXS for future facility expansion.

\section{A New Guideline for the Need of Significant Architectural Values}

The government should add new guidelines particularly for architecture characteristic and style of infill building and development in heritage site where 
PLANNING MALAYSIA

Journal of the Malaysia Institute of Planners (2018)

it must have certain significant architectural values and design direction to enhance the value and ambience of heritage site and building.

\begin{abstract}
Allocating Development Fund for New Development on Historical Heritage Site

The responsible ministry (The Ministry of Tourism and Culture - MOTAC) should intervene any new development that related to the historical heritage matters by providing extra fund and capital to that particular development to ensure the new physical development are not damaging and deteriorating the existing historical heritage building value and image of the site. The fund can be allocated specifically for the façade design of new infill building construction and the improvement of historical heritage facilities and materials. The responsible government bodies such as the National Heritage Department also have to be quick in identifying the potential heritage schools (building and site) to be listed for conservation and gazetted as national heritage.
\end{abstract}


Mohd Amirul Hakim Zamri \& Jamalunlaili Abdullah

Evaluation of Infill Building Block in Heritage Schools in Kuala Lumpur

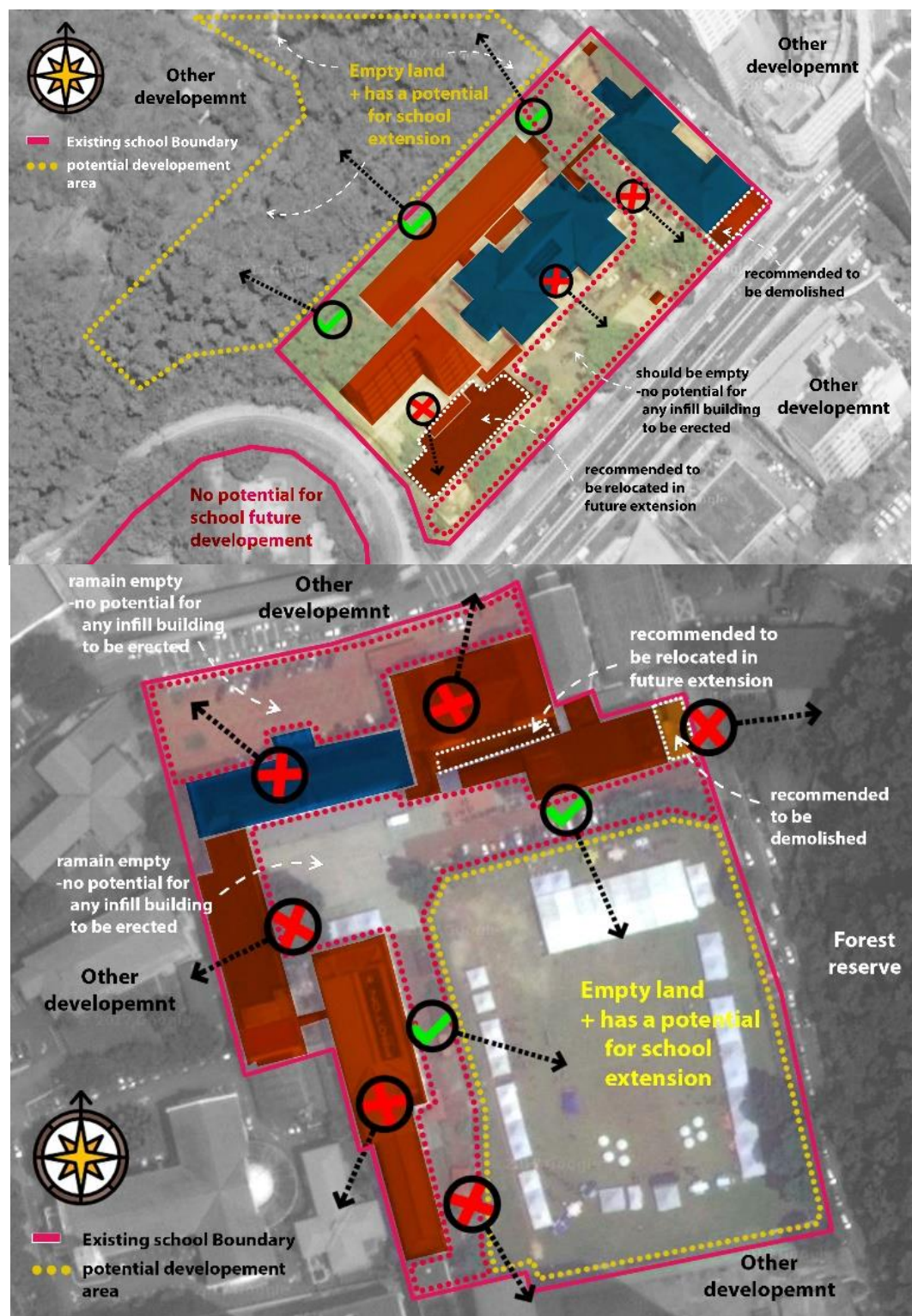

Figure 5: Recommendation of future planning at MXS (top) and SJI (bottom)

\section{Encourage Private Sectors to Adopt Heritage Schools}

The government could invite and encourage the private sector to adopt heritage schools. The agreement between the government and the private sector can be made with or without certain profitable interest. Expertise and fund from private sector could help in efforts to ensure future infill development at the schools will not jeopardise the historical value of the schools. 
PLANNING MALAYSIA

Journal of the Malaysia Institute of Planners (2018)

\section{Recommendation on the Development Adjacent to Heritage School}

\section{Monitor Design of Adjacent New Development Design}

The National Heritage Department and local authority should strictly check and monitor the design of new urban development adjacent to heritage schools, or any heritage sites, to ensure it complies and follows the requirement of conservation guidelines set by government. The new urban development should be sensitive to the existing historical heritage properties. The establishment and interest of a heritage building preservation should not be neglected when it collides with other urban development interest. This is because historical heritage is a national treasure.

\section{Control Height of Adjacent New Development Height}

To ensure the historical heritage school building (or other heritage buildings) can be seen from their majestic view angle, new developments that are located within 100meter radius of heritage schools shall not be developed too high to maximise the grand view toward the historical heritage school building. The building can only be erected with a height that is within the height range of the heritage building.

\section{CONCLUSION}

This paper has analysed infill development at two heritage schools in Kuala Lumpur. It reviews on the urban infill design approaches in heritage site setting, especially at heritage school, and the related issues. There are two types of architectural infill design approaches that can be applied in heritage site especially heritage schools and both design approaches can be applied as long as they comply with the criteria of a good urban infill development design. The heritage school development and planning arrangement are influenced by the surrounding urban context. Thus, to ensure the sustainability of heritage schools, all related parties should be sensitive and strive to protect and enhance these national heritage treasures. 
Mohd Amirul Hakim Zamri \& Jamalunlaili Abdullah

Evaluation of Infill Building Block in Heritage Schools in Kuala Lumpur

\section{REFERENCES}

Abdullah, J., Ahmad Zaki, S., \& Syed Subli, S. H. (n.d). Historic educational institutions and its potential as heritage tourism in Malaysia. Retrieved from http://scholar.google.com.my/citations?user=t9VIzh0AAAAJ\&hl=en

Alauddin, K., Ishakt, M. F., Mohd Isa, H., \& Mohamad Sohod, F. (2016). The observation of defects of school buildings over 100 years old in Perak. MATEC Web of Conferences, 66, 00088.

Alfirevic, D., \& Simonovic-Alfirevic, S. (2015). Infill architecture: Design approaches for in-between buildings and "bond" as integrative element. Arhitektura $i$ Urbanizam, 2015(41), 24-39.

Center for Urban Policy Research, The State University Of New Jersey (2006). Infill Development Standards and Policy Guide. New Jersey: New Jersey Department of Community Affairs. Retrieved from https://www.state.nj.us/dca/divisions/codes/.../2006 _6_rev2007_4_infill_dev_stds.pdf

Rotondo, F., Selicato, F., Marin, V., \& Galdeano, J. L. (2018). Cultural territorial systems: Landscape and cultural heritage as a key to sustainable and local development in Eastern Europe. Cham: Springer International Publishing.

Schultz, M. S., \& Kasen, V. L. (1991). Encyclopedia of community planning and environmental management. Ann Arbor, MI: UMI Out of Print Books on Demand, University Microfilms International. 